\title{
DETEKSI BAKTERI Salmonella DAN Shigella PADA MAKANAN BURGER DI SUNGAI RAYA DALAM PONTIANAK
}

\author{
Lisa Apriani ${ }^{1}$, Rahmawati ${ }^{1}$, Rikhsan Kurniatuhadi ${ }^{1}$ \\ ${ }^{1}$ Program Studi Biologi, Fakultas MIPA, Universitas Tanjungpura, \\ Jl. Prof. Dr. H. Hadari Nawawi, Pontianak \\ email korespondensi: lisaapriani387@gmail.com
}

\begin{abstract}
Burger is one of the food in Indonesia that consists of bread, meat, vegetables, sauce, and mayonnaise. This study aims to detect the bacterial presence from genus Salmonella and Shigella in burger food sold in Sungai Raya Dalam, Pontianak. Samples were collected from the location consist of cooked whole burger, precooked bread, postcooked bread, precooked burger meat, postcooked burger meat, lettuce, tomatoes, cucumbers, sauce, and mayonnaise ware bought from six traders. Based on the research, sixty samples tested in Salmonella Shigella Agar (SSA) media showed that $28,33 \%$ samples was contaminated with by Salmonella and 3,33\% samples was contaminated by Shigella, this showed that burger samples in Sungai Raya Dalam Pontianak could be contaminated by bacteria members of the genus Salmonella and Shigella and exceed the threshold that has been determined by SNI is negative $/ 25 \mathrm{~g}$.
\end{abstract}

Keywords: Burgers, Salmonella, Shigella

\section{PENDAHULUAN}

Burger adalah salah satu makanan yang digemari masyarakat Indonesia yang tersusun atas roti, daging, sayuran, saus dan mayones (Ademi dan Rinanda, 2011). Menurut Waluyo (2005) kandungan nutrisi seperti karbohidrat, lemak dan protein pada makanan burger memungkinkan bakteri dapat tumbuh karena bakteri membutuhkan nutrisi seperti karbon, mineral, fosfor dan nitrogen. Burger banyak dijual di pinggiran jalan, kondisi ini dapat menyebabkan burger terkontaminasi oleh bakteri sekitar.

Kontaminasi bakteri patogen pada makanan dan minuman dapat menyebabkan berbagai macam penyakit seperti typhoid, diare, keracunan makanan dan lain sebagainya (Siagian, 2002). Menurut Ginting et al. (2013), penyakit-penyakit ini akan mudah menyerang orang yang mengalami penurunan daya tahan tubuh karena faktor dari dalam (intrinsik) maupun dari luar (ekstrinsik). Penyakit bawaan makanan atau keracunan makanan yang ditimbulkan akibat adanya kontaminasi oleh bakteri patogen perlu mendapat perhatian secara seksama, karena penderita kasus ini dapat mengalami gangguan pencernaan dan gangguan penyerapan zat-zat gizi.
Salmonella dan Shigella merupakan salah satu bakteri penyebab infeksi pada manusia. Salmonella dan Shigella dapat mencemari makanan seperti telur mentah, daging mentah, sayuran segar, dan air yang tercemar (Waluyo, 2005). Salmonella dan Shigella masuk ke dalam tubuh manusia melalui mulut bersama makanan dan minuman yang tercemar, ditularkan melalui tangan, lalat atau serangga, mampu bertahan hidup dalam suasana beku atau kering (jawetz et al., 2005). Makanan jajanan seperti burger, selain faktor gizi, juga perlu diperhatikan faktor sanitasi dan higienitasnya (Judarwanto, 2006).

Beberapa penelitian menunjukkan bahwa sampel daging burger dapat terkontaminasi oleh bakteri. Berdasarkan penelitian yang telah dilakukan oleh Ginting (2005) menunjukkan bahwa terdapat 2 sampel daging burger yang dijual di sekitar kampus USU Medan dinyatakan positif terkontaminasi bakteri anggota spesies $E$. coli dan 8 sampel tidak terdapat anggota genus bakteri $E$. coli, serta seluruh sampel memberikan hasil negatif terhadap bakteri anggota genus Salmonella. Penelitian lainnya yang dilakukan oleh Ginting et al. (2013) mengenai hygiene, sanitasi dan analisa pencemaran anggota genus Salmonella, terdapat 
bakteri anggota genus Salmonella pada sampel daging burger sebelum digoreng sedangkan pada sampel daging burger sesudah digoreng hanya terdapat 1 sampel yang mengandung bakteri anggota genus Salmonella yang dijual di Kelurahan Helvetia Timur Kecamatan Medan. Hal ini menunjukkan bahwa sampel burger dapat terkontaminasi bakteri anggota genus Salmonella. Penelitian ini bertujuan untuk mengetahui jumlah mikroba pada makanan burger dan mendeteksi keberadaan bakteri anggota genus Salmonella dan Shigella pada makanan burger yang dijual dilokasi Sungai Raya Dalam kota Pontianak

\section{BAHAN DAN METODE \\ Waktu dan Tempat Penelitian}

Penelitian ini dilakukan selama 2 bulan, yaitu pada bulan Juli hingga September 2018, yang mencakup pengambilan sampel di lapangan, pengujian sampel dan pengolahan data. Pengambilan sampel makanan burger dilakukan di beberapa titik lokasi penjualan kedai burger di Sungai Raya Dalam. Pengujian sampel dilakukan di Laboratorium Mikrobiologi, Jurusan Biologi, Universitas Tanjungpura, Pontianak.

\section{Bahan}

Bahan yang digunakan pada penelitian ini adalah alkohol 70\%, akuades, kristal violet, larutan iod, makanan burger, media Nutrient Agar (NA), Nutrient Broth (NB), Salmonella-Shigella Agar (SSA), safranin, spritus.

\section{Prosedur Kerja}

\section{Sterilisasi Alat}

Alat-alat kaca berupa cawan petri, gelas beker, gelas ukur dan tabung reaksi dicuci bersih terlebih dahulu lalu dikeringkan dan disterilisasi menggunakan autoklaf dengan tekanan 2 atm dan suhu $121^{\circ} \mathrm{C}$ selama 15 menit (Marlina, 2008).

\section{Pengambilan Sampel}

Pengambilan sampel makanan burger dilakukan secara acak (random sampling) pada penjual burger, dengan cara dibeli sebanyak 3 burger yang terdiri dari 1 sampel burger utuh yang telah dimasak, 1 sampel burger yang tidak dimasak yang diambil secara terpisah (roti sebelum dimasak (RBM), daging sebelum dimasak (DBM), sawi, tomat, mentimun, saus dan mayones) dan 1 sampel burger yang telah dimasak yang diambil secara terpisah (roti setelah dimasak (RM) dan daging setelah dimasak (DM). Sampel kemudian dimasukkan ke dalam plastik dan cool box, kemudian dibawa ke Laboratorium Mikrobiologi, Fakultas Matematika dan Ilmu pengetahuan Alam, Universitas Tanjungpura Pontianak.

\section{Pengenceran}

Sampel burger yang telah diambil dari toko dipotong menjadi bagian-bagian kecil, kemudian dihaluskan menggunakan blender. Sampel sebanyak 1 gram diambil dan dimasukkan ke dalam tabung reaksi yang berisi $9 \mathrm{ml}$ akuades steril sebagai pengenceran awal, kemudian dihomogenkan menggunakan vortex. Pengenceran $10^{-2}$ dilakukan dengan mengambil suspensi dari pengenceran awal sebanyak $1 \mathrm{ml}$ dan dipindahkan ke tabung reaksi yang berisi $9 \mathrm{ml}$ akuades dan dihomogenkan, selanjutnya dibuat pengenceran $10^{-}$ ${ }^{3}, 10^{-4}$ dan $10^{-5}$ dengan cara yang sama (Waluyo, 2008).

\section{Deteksi Salmonella-Shigella}

Deteksi bakteri Salmonella dan Shigella dilakukan dengan menggunakan media spesifik SalmonellaShigella Agar (SSA). Sebanyak $1 \mathrm{ml}$ suspensi dari masing-masing seri pengenceran $\left(10^{-3}\right.$ sampai $\left.10^{-5}\right)$ diinokulasikan ke dalam tabung reaksi yang berisi agen perkaya Nutrient Broth (NB) sebanyak $9 \mathrm{ml}$ kemudian dihomogenkan dan diinkubasikan pada suhu $37^{\circ} \mathrm{C}$ selama $1 \times 24$ jam. Sampel yang telah dilakukan pengayaan diambil menggunakan cotton bud steril kemudian di goreskan pada permukaan media SSA dengan rata secara zig-zag. Inkubasi pada suhu $37^{\circ} \mathrm{C}$ selama $2 \times 24$ jam (Rahmiati, 2016).

\section{Analisis Data}

Penelitian ini bersifat observatif dan deskriptif. Data yang diperoleh didokumentasikan dalam bentuk foto, ditubulasikan ke dalam tabel dan dideskripsikan berasarkan hasil pengujian, karakteristik.

\section{HASIL DAN PEMBAHASAN}

\section{Hasil}

Deteksi Bakteri Salmonella-Shigella pada Makanan Burger

Keberadaan Salmonella dan Shigella dapat diketahui dengan cara menginokulasikan sampel pada media Salmonella Shigella Agar. Hasil penelitian menunjukkan bahwa $66,67 \%$ sampel 
burger utuh mengandung bakteri anggota genus sebelum dimasak (DBM) mengandung bakteri anggota genus Salmonella dan $16,67 \%$ mengandung bakteri anggota genus Shigella, 100\% sampel sawi mengandung bakteri anggota genus Salmonella dan $16,67 \%$ mengandung bakteri anggota genus Shigella, 50\% sampel tomat mengandung bakteri anggota genus Salmonella, dan 33,33\% sampel mentimun mengandung bakteri anggota genus Salmonella (Gambar 1).
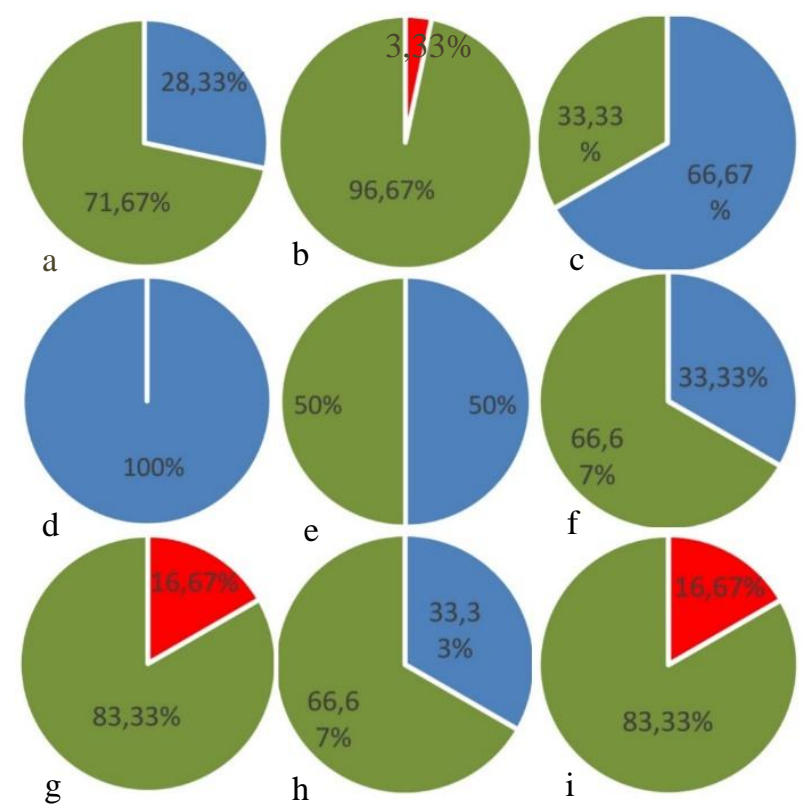

Gambar 1. Persentase deteksi bakteri SalmonellaShigella pada makanan burger : a Persentase Salmonella pada semua sampel, b. Persentase Shigella pada semua sampel, c. Persentase Salmonella pada burger utuh, d. Persentase Salmonella pada sampel DBM, e. Persentase Salmonella pada sampel sawi, f. Persentase Salmonella pada sampel tomat, g. Persentase Salmonella pada sampel mentimun, h. Persentase Shigella pada sampel DBM, i. Persentase Shigella pada sampel sawi.

Keterangan : $\square$ Positif Salmonella, $\square$ Positif Shigella, प Tidak Terdeteksi

\section{Pembahasan}

\section{Deteksi Salmonella dan Shigella pada Makanan Burger}

Hasil isolasi pada media Salmonella Shigella Agar (SSA) yang positif mengandung bakteri anggota genus Shigella ditunjukkan dengan terbentuknya koloni bening tanpa bintik hitam karena bakteri anggota genus Shigella tidak meragi laktosa dan tidak menghasilkan gas $\mathrm{H}_{2} \mathrm{~S}$ (Isenberg, 1992). Bakteri dari anggota genus Salmonella dapat menghasilkan $\mathrm{H}_{2} \mathrm{~S}$ dan tiosulfat reduktase sehingga akan membentuk koloni bening dengan bintik
Salmonella, 33,33\% sampel daging hitam di bagian tengah serta menimbulkan bau. Bakteri Salmonella menggunakan pepton yang berasal dari media SSA untuk sumber energi. Menurut Muktiningsih et al. (2016), SSA adalah media selektif untuk mengisolasi bakteri anggota genus Salmonella dan bakteri anggota genus Shigella, tetapi media SSA tidak disarankan untuk pengujian bakteri anggota genus Shigella karena beberapa strain Shigella akan terhambat.

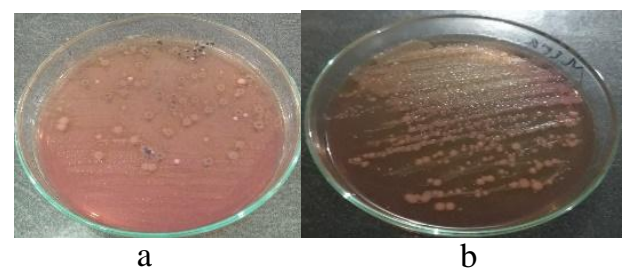

Gambar 2. Koloni bakteri (a. Positif Salmonella, b. Positif Shigella)

Shigella merupakan bakteri gram negatif berbentuk batang, tunggal, tidak memiliki flagel, aerobik ataupun aerobik fakultatif dan tidak membentuk spora, serta habitatnya berada pada saluran pencernaan dengan infeksinya melalui fase oral (Aini, 2018). Salmonella merupakan bakteri gram negatif berbentuk batang, tidak berspora, bersifat anaerob fakultatif dan bergerak dengan flagel peritrik kecuali Salmonella pullorum dan Salmonella gallinarum ( Jawetz et al., 2005).

Makanan yang mengandung bakteri seperti Salmonella dalam jumlah kecil tidak akan merubah bentuk, warna, rasa dan baunya sedangkan Salmonella dalam jumlah yang banyak akan membuat perubahan pada bentuk, warna, rasa dan bau khas yang ditimbulkan bakteri (Mukono, 2000). Makanan yang berasam rendah seperti daging, telur ikan dan produk olahannya merupakan sumber infeksi dan keracunan oleh bakteri. Bakteri anggota genus Salmonella merupakan bakteri patogen yang menjadi indikator bahwa makanan tersebut kualitasnya sudah menurun dan apabila tertelan mengakibatkan penyakit saluran pencernaan. Bakteri ini dapat menyebar melalui alat pengolahan yang digunakan kurang higiene dan waktu penyimpanan yang terlalu lama (Dharmojono, 2001).

Hasil penelitian menunjukkan bahwa pada sampel burger utuh terdapat $66,67 \%$ sampel mengandung anggota genus Salmonella. Daging sebelum dimasak (DBM) terdapat 33,33\% sampel yang mengandung bakteri anggota genus Salmonella, 
sedangkan pada daging setelah dimasak tidak terdapat bakteri anggota genus Salmonella, hal ini disebabkan pada saat penggorengan daging burger tersebut digoreng pada suhu yang mematikan bakteri anggota genus Salmonella karena bakteri ini dapat mati dengan pemanasan sampai $54,4^{\circ} \mathrm{C}$ selama 1 jam dan $60^{\circ} \mathrm{C}$ selama 15 menit (Judarwanto, 2006).

Daging sebelum dimasak (DBM) terdapat 33,33\% yang mengandung bakteri anggota genus Salmonella dan $16,67 \%$ mengandung bakteri anggota genus Shigella. Penelitian yang dilakukan oleh Kheiry et al (2014) menemukan bahwa $17,81 \%$ daging dan daging olahan kemasan dan non-kemasan di Teheran mengandung anggota genus Salmonella. Menurut Elisa dan Srianta (2003) faktor yang menyebabkan terkontaminasi bakteri yaitu dari bahan makanan yang terinfeksi bakteri Salmonella, kebersihan lingkungan peternakan serta cara pengolahan daging yang tidak masak.

Hasil penelitian menunjukkan bahwa sampel sayuran sawi $100 \%$ mengandung bakteri anggota genus Salmonella, 50\% sampel tomat dan 33,33\% sampel mentimun, hal ini tidak sesuai dengan ketentuan BPOM RI HK.00.06.1.52.4011 yaitu sayuran sebaiknya tidak terdapat bakteri nggota genus Salmonella (negatif/25g). Menurut Lund et al (2000), sayuran merupakan salah satu bahan makanan yang mudah terkontaminasi bakteri anggota genus Salmonella, hal ini dapat dilihat pada sawi yang positif mengandung bakteri anggota genus Salmonella. Berdasarkan survei yang dilakukan oleh Susilawati (2002) menyatakan bahwa proses penyiraman dan pencucian sayuran menggunakan air yang tidak bersih dapat menjadi sumber kontaminasi mikroba. Berdasarkan hasil pertanyaan kepada responden bahwa air yang mereka gunakan untuk pencucian sayuran menggunakan air yang tidak dimasak, hal ini menunjukkan bahwa air merupakan salah satu sumber yang dapat menyebabkan kontaminasi. Sampel burger untuk bahan sayurannya tidak dilakukan pengolahan sehingga sayuran dalam keadaan mentah, hal ini juga dapat menyebabkan terkontaminasi bakteri anggota genus Salmonella. Menurut Elisa dan Srianta (2003), selain dari bahan makanan yang mengandung bakteri anggota genus Salmonella, proses pengolahan bahan makanan juga dapat menjadi faktor pertumbuhannya. Pengolahan makanan yang baik meliputi cara pemasakan, dari segi waktu dan suhu pemasakan harus diperhatikan.

\section{DAFTAR PUSTAKA}

Ademi, BF, \& Rinanda, T, 2011, Deteksi Cemaran Escherichia coli pada Daging Burger Penjual Kaki Lima Di Desa Kopelma Darussalam dan Restoran Cepat Saji Di Banda Aceh, Jurnal Kedokteran Syiah Kuala, vol.11, no.3, hal.134142

Aini, F, 2018, Isolasi dan Identifikasi Shigella $s p$. Penyebab Diare pada Balita, Jurnal Bio-site, Vol. 4, No. 1, hal. 1-40

Badan POM RI, 2011, Peraturan Kepala Badan Pengawas Obat dan Makanan Republik Indonesia Nomor HK.03.1.23.08.11.07331, BPOM, Jakarta

Dharmojono, 2001, Kapita Selekta Kedokteran Veteriner, Pustaka Populer Obor, Jakarta

Elisa, R \& Srianta, 2003, Deteksi Salmonella pada Nasi Goreng yang Disediakan oleh Restoran Kereta Api Kelas Ekonomi, Jurnal Teknologi dan Industri Pangan, vol. 14, no. 3

Ginting, WNP, Santi, DN \& Chahaya, I, 2013, Hygiene Sanitasi dan Analisa Pencemaran Salmonella sp. Pada Daging Sapi Olahan (Daging Burger) Sebelum dan Sesudah Digoreng yang Dijual Di Kelurahan Helvetia Kota Medan, Skripsi, Universitas Sumatera Utara, Medan

Ginting, EP, 2005, Kandungan Bakteri Escherichia coli dan Salmonella sp. pada Daging Burger yang Dijual Di Sekitar Kampus USU Medan, Skripsi, Universitas Sumatera Utara

Isenberg, HD, 1992, Interpretation of Aerobic Bacterial Growth on Primary Culture Media, Clinical Microbiology Procedures Handbook, Vol. 1, hal. No. 1, hal. 61-67

Jawetz, Melnick \& Adelberg's, 2005, Mikrobiologi Kedokteran, Salemba medika, Jakarta

Judarwanto, 2006, Hubungan Pola Konsumsi Makanan Jajanan dengan Status Gizi dan Fungsi Kongnitif Anak Sekolah Dasar, Skripsi, Surakarta

Lund, BM, Baird Parker, TC, Gould, GW, 2000, The Mikrobiological Safety and Quality of Food, Aspen Publisher Inc, Gathersburg Maryland 
Mukono, HJ, 2000, Prinsip Dasar Kesehatan Lingkungan, Airlangga University Press, Surabaya

Muktiningsih, F, Kurniadewi \& Immanuel, ORP, 2016, Isolasi Amflikasi dan Sekuensing Fragmen 1,9 Kilobasa Gen Heat Shock Protein 70 Salmonella enterica Serovar Thypi, Jurnal Kimia dan Pendidikan Kimia, vol. 11, no. 1, hal. 32-40

Rahmiati, 2016, Analisis Bakteri Salmonella-Shigella pada Kuah Sate Pedagang Kaki Lima, BioLink, vol. 3 , no. 1 , hal. 31-36
Siagian, A, 2002, Mikroba Patogen Pada Makanan Dan Sumber Pencemarannya, USU Digital Library, Fakultas Kesehatan Masyarakat Universitas Sumatera Utara

Susilawati, A, 2002, Keamanan Mikrobiologi dan Survey Lapangan Sayuran di Tingkat Petani dan Pasar Tradisional di Daerah Bogor, Skripsi, Fateta IPB, Bogor

Waluyo, L, 2008, Teknik metode dasar mikrobiologi, Universitas Muhamadiyah Malang Press, Malang

Waluyo, L, 2005, Mikrobiologi Umum, Universitas Muhamadiyah Malang Press, Malang 